\title{
Accounting for Fishermen Tribe Using (An Ethnographic Approach)
}

\author{
Dian Pratama ${ }^{1}$, Indah Prastiwi ${ }^{2}$, Riski Isminar Ardianti ${ }^{3}$ \\ \{dian.pratama-2017@ feb.unair.ac.id ${ }^{1}$, indah.prastiwi-2016@ feb.unair.ac.id ${ }^{2}$, isminar58@gmail.com ${ }^{3}$ \} \\ Accounting Department, Airlangga University, Surabaya, Indonesia ${ }^{1,2,3}$
}

\begin{abstract}
Using is a tribe that exists only in Banyuwangi. Using ethnic majority living area of coastal fishermen. Using tribal fishing communities have a habit as the society in general, they work to meet their needs. This research aims to study the correlation between tribal fishermen Using the simple accounting process using an ethnographic approach. The uniqueness of this study is to find a correlation between the Using tribal fishing culture with modern accounting theory. This study uses a qualitative method based ethnography. Data obtained from respondents and documents Using the tribe. Analysis of the data using the method of triangulation data. The findings from this study, Using tribal fishermen have standards that are passed from generation to generation. In economics and accounting activities of the day - rate fishermen Using applying the conceptual framework of principles of conservatism, agency theory, recording cash basis and CSR are realized with Pethik Laut.
\end{abstract}

Keywords: Fishermen, Accounting, Using tribe, Ethnography

\section{Introduction}

Banyuwangi is a district located in the eastern end of the Java island that has a variety of cultural and natural resources. Banyuwangi has a native tribe called $U$ sing tribes. The natives of this Banyuwangi spread across several districts in Banyuwangi, Using tribal communities profession depends on the neighborhood, to those who reside coastal areas such as the area Blimbingsari, Muncar, and Banyuwangi mostly fishermen.

Fisherman is a person whose livelihood is fishing (UU. No. 45 of 2009). Those that describe the fisherman is a person who is actively doing work in fishing operations or take advantage of other marine resources [1]. As society in general, Using tribal fishermen work daily to generate income to meet daily needs - today and investment [2]. As accounting principles, any income should be balanced with the financing, spending and investment. Accounting is economics that contain other disciplines such as mathematics, management, and planning.

Accounting can serve as a medium for the financial statements in the input, process and output will be a guide in acting for the parties concerned. The result of accounting is representative of the actual situation and should be maintained Objectivity with evidence based on accounting transactions and formal guidelines.

A paradigm states that there are fundamental differences in financial accounting in a small scope and accounting in the business cycle. Whereas in the preparation of financial statements 
there are several environmental and cultural influences. For this reason, this research will be Examined at the accounting level of fishermen Using in terms of ethnography.

Ethnographic research can also be used in exploring and describing the accounting life in the Midst of social interaction. Ethnographic research not only observing human behavior, but Also interpret the behavior that can be framed in the scientific life of accounting. Based on this background, this study will examine how applying accounting Osing ethnic groups in everyday life starts from the process until the output and the level of compliance with accounting methods.

\section{Literature Review}

\subsection{Using Tribal Fishermen}

Fisherman is a person whose livelihood is fishing (UU. No. 45 of 2009). Those that describe the fisherman is a person who is actively doing work in fishing operations or take advantage of other marine resource [3]. Using tribal fishermen is an Using tribe society who works as a fishermen, and they trust and preserve Using tribe culture in their activity [4].

\subsection{Using tribe}

Using tribal history began when the fall of Majapahit, the start of the war Paregreg and growth of Islamic kingdom in Java. Blambangan be part of the kingdom of Majapahit kingdom since 1295 until 1527 [5]. After the fall of Majapahit by the Malacca sultanate, empire Blambangan be stand-alone. However, within two centuries, between the years 1546 1764, the kingdom was subjected conquest Blambangan surrounding kingdoms. The seizure of power is what affects the occurrence of migration, displacement royal capital and the emergence of new settlements. They evacuated to different places, to the slopes of Mount Bromo (Tengger), Bali, Blambangan (Using tribes) who we now know as Banyuwangi.[6]

\subsection{Accounting}

Accounting is one area of economics that it contains other disciplines such as mathematics, management and planning. In accounting science disciplines is more frequently used is about making the financial statements. The financial statements of the financial information presented and prepared by the management of a company to the internal and external parties that contains all the business activities of an entity the which is one of accountability and communication management tools to Reviews those in need.

\subsection{Ethnography}

Ethnography or ethnographic, means describe or depict the life of a community or nation. Ethnography is an anthropologist job in describing and analyzing the culture, Whose game objective is to understand pastures (knowledge) and its relationship to daily life (behavior) in order to get a view about "world" communities studied. Additionally, ethnography can Contribute guided cultural ties in the social sciences in order to describe in detail the theories natives.

\section{Research Methodology}

This type of research used in this study is a qualitative research, with due consideration to deal with the fact multiple serving directly the nature of the relationship between Researchers and informants, and this method is more sensitive and more Able to adjust to a lot of 
sharpening effect along with patterns of value faced. Qualitative research does not have a pure method hers so take advantage of Semiotics, narrative analysis, phonemic event statistics. The methods and approaches used can be various kinds ranging from phenomenology, hermeneutics, feminism, deconstructionism, ethnometodology, psychoanalysis, ethnography, participant observation. Our Obtained Data is based on triangulation of data items, namely direct observation, study literatur, in-depth interviews, and focus group discusions. The data processing techniques are data reduction, data display and analysis, conclusion drawing and verification [7].

\section{Results and Discussion}

Using a tribal fisherman communities living in coastal areas such as Muncar, Blimbingsari, and Banyuwangi which works by utilizing the natural resources of the sea. As society in general, Using tribal fishermen work to finance their daily needs[8], As each accounting principles must be balanced with financing income, expenses and investments. Using tribe has applied the accounting principles with their interpretation of its own and has been applied down - to become a cultural generations [9].

\subsection{Application of Accounting Theory on Using tribe Fishermen}

\subsubsection{Conceptual Framework}

The conceptual framework is a system that is interconnected and consists of objectives and basic concepts are interrelated, which became the basis for the establishment of a consistent standard, determining the nature, function, and limits - the limits of accounting and financial statements. Using tribal fishermen using the theory of a conceptual framework to define their rules and accounting standards, which consists of the application of the principle of conservatism, agency theory, recording on cash basis, assess the LIFO inventory method, and implement Corporate Social Responsibility are relized by Pethik Laut

\subsubsection{Conservatism}

Conservatism principle is a principle which states that the company in carrying out the functions of their business activities shall be careful - careful, to avoid errors in both operational and decision-making [10]. Conservatism can also be interpreted as a behavior that anticipates profits and anticipate all possible losses.

Using tribal fishermen interpret this by trusting their conservatism na'as day. Na'as day is a day believed to be the bearer of bad luck, so the fishing communities Using the tribe would avoid these days, in a way not to go to sea. Using tribal fishermen generally believe that day na'as occur every Tuesday and Friday. Using tribal fishermen also believe na'as day in every month, as shown bellow.

Table 1. Na'as Day Schedule in Every Month

\begin{tabular}{ll}
\hline Java's Islamic Months & Na'as Day \\
\hline Ramadhan, Syawwal, Dzulqa'dah & Friday \\
Dzulhijjah, Muharram, Shafar & Saturday and Sunday \\
Rabi'ul awal, Rajab, Sya'ban & Wednesday and Thursday \\
Rabi'ul Akhir, Jumadil Awal, Jumadil Akhir & Monday and Tuesday \\
\hline
\end{tabular}

\subsubsection{Agency Theory}

Agency theory is a theory that explains the relationship between the owner of the company (shareholders) and management manager [11], In this theory, the manager called the 
agent management, while the owner of the company called the principal[12], This theory arises when business owners employ others to manage its business.[13]

Using tribal fishermen to apply this theory in their business activities. The owner of the boat or fishing skipper (Principal) will employ fishermen who do not have a boat or fishing boat called fishermen Pandega (agent) [14], Profit sharing is usually done with a ratio of 50: 50 .

\subsubsection{Recording Using a Cash Basis}

Cash basis accounting is a method of recording transactions, where the transaction occurred recently recorded after the cash has been received or issued. [15]. Using tribal fishermen apply the cash basis method of recording and managing their finances. Using tribal fishermen usually deduct the cash balance on their records when they use it to pay expenditure, and add their current cash balances earn revenue from fish catches.

\subsubsection{LIFO Inventory Method}

LIFO, or Last in first out is an inventory valuation method in accounting. This method means that the value or price of the last supplies entered is first recorded as cost of goods sold. [16] Using Tribe fishermen rate using this method in determining the cost of their sales. Using tribal fishermen will use the recent market price in selling the fish catch.

4.1.6. Corporate Social Responsibility (CSR)

Corporate Social Responsibility is a concept that an operation unit having various forms of responsibility towards all stakeholders, in all aspects of the like economic, social, and environmental [17]. CSR also defined as a company's contribution to the goals of sustainable development by impact management (minimize the negative impacts and maximize the positive impacts) for all stakeholders [18].

Using tribal fishermen to apply Corporate Social Responsibiity through Pethik Laut [1]. Pethik Laut is a marine ceremonial presenting sesaji for the sea, as the gratitude of the catches of the fish were abundant, as well as for safety in their business. Pethik Laut commonly carried out at the beginning of the count of Java, or the Muharram month.

\section{Conclusion}

Basically accounting is applied science in business management and economics. Not only the formal business, accounting is also applicable in daily activity. Fisherman Using tribal communities is one example of how accounting is applied in everyday life - their day, by their interpretations, which became their culture.

Cultures that is their interpretation of the theories of the existing accounting, must continue to be preserved, in order to remain a richness of Indonesian culture. The younger generation should Using parts together - equally determined to preserve the remains of the culture of their ancestors.

\section{References}

[1] N. Ainiyah, "PETIK LAUT : Social-Ideological Accommodation in the Fishermen Community of Kedungrejo Muncar Banyuwangi," RELIGIA, vol. 20, no. 2, pp. 145-159, 2017.

[2] M. A. M. Karper and P. F. M. Lopes, "Punishment and compliance : Exploring scenarios to improve the legitimacy of small-scale fi sheries management rules on the Brazilian coast," Mar. Policy, vol. 44, pp. 457-464, 2014.

[3] N. Colbert-sangree and J. F. Suter, "Community based fi shery management within the Menai 
Bay conservation area : A survey of the resource user," Mar. Policy, vol. 60, pp. 171-177, 2015.

[4] I. Muflikhati and Et.al, "KONDISI SOSIAL EKONOMI DAN TINGKAT KESEJAHTERAAN KELUARGA : KASUS DI WILAYAH PESISIR JAWA BARAT,” J. Ilm. Kel. Kons, vol. 3, no. 1, pp. 1-10, 2010.

[5] R. M. Hariastuti, "RUMAH ADAT USING BANYUWANGI : KAJIAN BUDAYA DALAM MEDIA PEMBELAJARAN MATEMATIKA," in FKIP UNIVERSITAS PGRI BANYUWANGI SEMINAR NASIONAL Pendidikan Budaya dan Sejarah "Dibalik Revitalisasi Budaya," 2018, pp. 56-64.

[6] T. F. Huda and A. T. Firdaus, "TANTANGAN MASYARAKAT MARITIM PASCA TSUNAMI DI," in FKIP UNIVERSITAS PGRI BANYUWANGI SEMINAR NASIONAL Pendidikan Budaya dan Sejarah "Dibalik Revitalisasi Budaya," 2018, pp. 122-127.

[7] S. J. Breslow, "Accounting for neoliberalism : 'Social drivers ' in environmental management," Mar. Policy, vol. 61, pp. 420-429, 2015.

[8] S. Rindawati, "STRATEGI PENINGKATAN MASYARAKAT NELAYAN DI KOTA BENGKULU," J. Ekon. DAN Inf. Akunt., vol. 2, no. 3, pp. 291-314, 2012.

[9] A. Sarah, L. Richmond, and D. Lopez-carr, "Marine resource management : Culture , livelihoods , and governance," Appl. Geogr., vol. 59, pp. 56-59, 2015.

[10] J. Raymond-yakoubian and Et.al, "The incorporation of traditional knowledge into Alaska federal fi sheries management," Mar. Policy, vol. 78, no. January, pp. 132-142, 2017.

[11] V. A. Qurrata, "PATRON CLIENT : KONTRAK SEMI MUDHARABAH DALAM TEORI KEAGENAN DI PERIKANAN LAUT," Fak. Ekon. Univ. Negeri Malang, no. 5, pp. 1-8.

[12] U. Dressel, "Agency theory perspective on public-private-partnerships : international development project,” Int. J. Product. Perform. Manag., no. January, 2018.

[13] W. Reim, D. Sjödin, and V. Parida, "Mitigating adverse customer behaviour for product-service system provision : An agency theory perspective," Ind. Mark. Manag., no. April, pp. 1-12, 2018.

[14] M. Imron and A. Wahyono, "PENELITIAN SOSIAL BUDAYA MARITIM PADA PUSAT PENELITIAN KEMASYARAKATAN DAN KEBUDAYAAN-LIPI DAN SUMBANGANNYA PADA KEBIJAKAN PEMERINTAH DI BIDANG KELAUTAN DAN PERIKANAN," J. Masy. dan Budaya, vol. 20, no. 1, pp. 123-142, 2018.

[15] N. Rahmawati, "Implementasi Standar Akuntansi Pemerintahan Berbasis Akrual di Sekretariat DPRD Kabupaten Malang Berdasar Peraturan Pemerintah Nomor 71 Tahun 2010," J. unikama, 2016.

[16] C. K. Jaggi, S. K. Goel, S. Tiwari, and N. A. Block, "TWO-WAREHOUSE INVENTORY MODEL FOR NON-INSTANTANEOUS DETERIORATING ITEMS UNDER DIFFERENT DISPATCH POLICIES,” Rev. Investig. OPERACIONAL, vol. 38, no. 4, pp. 343-365, 2017.

[17] M. Hidayaturrahman, "CORPORATE SOCIAL RESPONSIBILITY STRATEGI KOMUNIKASI PERUSAHAAN MIGAS,” J. Nomosleca, vol. 3, no. 2, pp. 614-624, 2017.

[18] J. Mandley, "Peranan Pemerintah Daerah Dalam Meningkatkan Kinerja Corporate Social Responsibility ( CSR ) Di PT . Nusa Halmahera Minerals," J. Adm. publik, 2009. 